\title{
THE POETRY'S POTENCIES AS EMOTION THERAPY MEDIA IN SOCIETY 5.0
}

\author{
Siti Fatimah, Ngatmini, and Latif Anshori Kurniawan \\ Universitas PGRI Semarang \\ e-mail: fatimah_juwana@yahoo.com,
}

\begin{abstract}
(Title: The Poetry's Potencies As Emotion Therapy Media in Society 5.0). This study aims to describe the function of poetry as a medium for emotional therapy in society 5.0. The data from this study are poetry texts written by students. Data were collected through test techniques (poetry writing) and non-tests (interviews, observations, and documentation). Based on the results of the study, it is said that aside from being a medium for brainstorming one's thoughts, feelings, and experiences, poetry has the potential to become a medium for emotional therapy. Dictionaries, Enjambments, typography, and arrangement of lines can be said to represent the soul of the poet when angry, happy, in love, traumatized, experiencing sadness, and other emotions. The entire contents of the poem are a reflection of the emotions that the poet naturally experienced, saw, and felt in the packaging of words that were solid and full of meaning.
\end{abstract}

Keywords: poetry, emotion therapy, therapy media, society 5.0

\section{INTRODUCTION}

This article is motivated by concern for the younger generation who are now more familiarly referred to as millennials with rude behavior and impolite speeches. Especially on the news about the quarrel with the famous lawyer Nikita Mirzani, namely Elsa Syarif, in a talk show. The news then became a trending topic on social media and YouTube, seen by thousands and even millions of citizens, not to mention those published via Instagram. This phenomenon is blacklisted and a kind of pollution in public spaces for days, weeks, months, even digital records are not easily erased. In addition to the case of the Nikita feud (2019), there is another not less uproar in the social media scene that is Barbie Kumalasari who threat Wulan Ye (2019).

Both disputes are only examples of a small part of the reality of life that occurred in the Indonesian nation. It crossed the way of educating parents to both when they were children. Usually a person's character can be influenced by parenting and the influence of people in the surrounding environment. In addition, the thing that influences the foundation of one's character is the reference that becomes the reading material, in this case includes literary works that are read and absorbed, which generally are in the form of prose, both short stories and novels (Dewi, 2018; Hardila, 2018). Then what about literary works in the form of poetry? Does poetry have potential and have power similar to prose?

Besides having aesthetic value, providing a sensation of beauty through implicit meanings, spoiling readers with dense but multi-interpretative diction, other functions of poetry seem to have been investigated through various studies, including as a way to provide therapy to someone (Karyanta, 2012; Farikha, 2015 ; Kusumawardhani, 2017, Permana, 2019). The term of Elirica (2013) also appears as an implication of the use of poetry as a way to provide such therapy. In studies that have been done before, used poems of others, which have generally been published even popular, not the result of the creation of a person who is being treated, both for therapy through writing or reading. This is what distinguishes from studies of the potential of poetry as a process of providing therapy.

Not only that, the therapy in the previous research was not clearly intended for someone with a certain situation or condition, while in this study it was clearly intended for someone 
who had the potential to commit acts such as Nikita Mirzani or Barbie Kumalasari, who could not control their emotions, especially both of them living in community circles. which is no longer referred to as 4.0 era but 5.0 (everything that is on social media and supported by information technology tools has an impact on the civilization of communicating and living in the real and virtual or cyber world). This is in line with the theory put forward by Shinzo Abe that the era of 5.0 had the aim of balancing technological progress with integrated social problem solving (Puskomedia, 2019).

\section{METHOD}

This research is a literature study on the results of research on the use of poetry as therapy to someone, especially its potential to be used by society 5.0 related emotions. Society 5.0 targeted for students, with consideration that at this age is a period of searching and determining identity. Content analysis techniques and theory triangulation are used in research so that the potential for poetry to be known for the media of emotional therapy in society 5.0. This discovery is at the same time a new formula based on previous research and innovative thinking using paraphrasing techniques oriented to the forms and intentions/ meanings that are formulated from Crystal's thought (1985, 1220-221), Grady et al (1992: 232), and Fromklin \& Rodman (1993: 131 -132) for the improvement of poetry as a therapeutic medium that was applied to the people of 5.0 in the perspective of Shinzo Abe (Puskomedia, 2019). The determination of the theory is based on the character of Indonesian society today which is in the 4.0 to 5.0 era (the era of artificial intelligence) and also various types of poetry that tend to exist and were created in Indonesia.

\section{RESULTS AND DISCUSSION Results}

Life is so dynamic, almost all aspects change, and this change cannot be separated from the development of science and technology. The evolution of life from the 1.0 to 5.0 eras can be seen in the following figure.

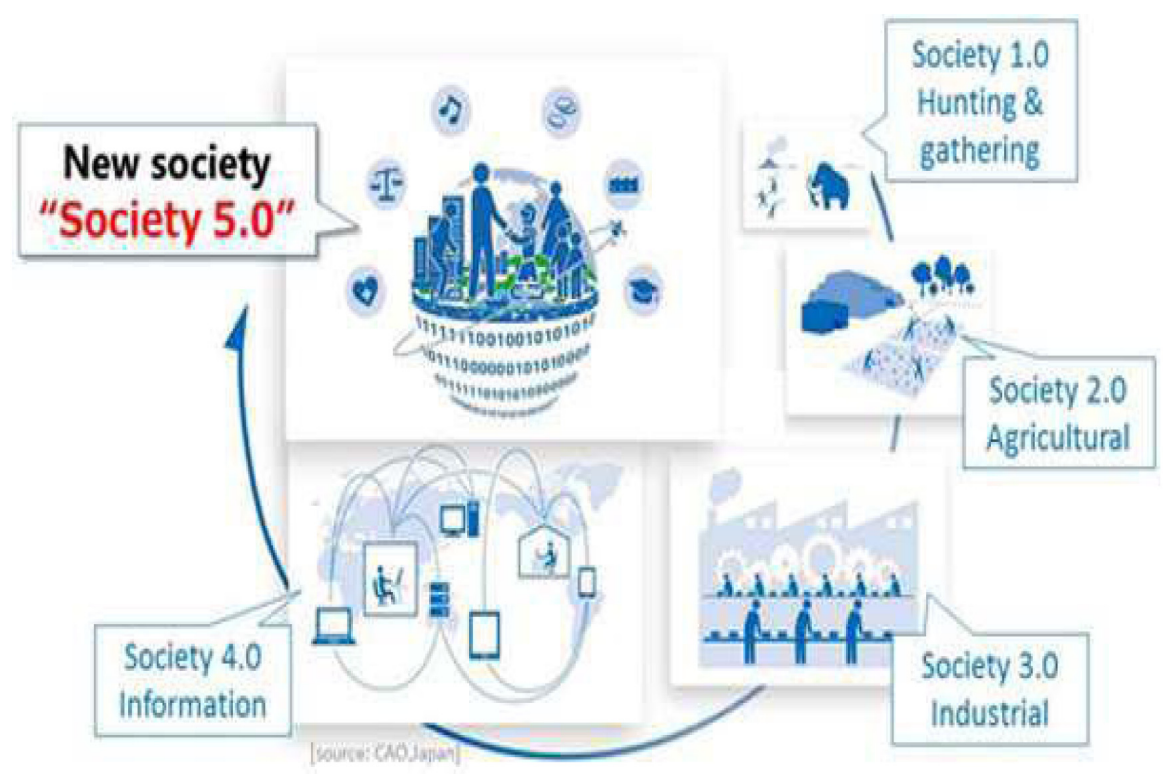

Figure 1. Development of Human Life Towards Society 5.0

(Puskomedia, 2019) 
Shinzo Abe's perspective regarding society 5.0 can be seen from the following statement (Puskomedia, 2019).

In society 4.0 or better known as industry 4.0, new people are familiar with technology, openness and ease of getting information are the positive impact of that era. Along with the rapid development of technology, the use of technology began to increase its role in human life and the era of society 5.0 is an era where technology is very close to human life. The era of society 5.0 was first introduced with the aim of balancing technological progress with integrated social problem solving.

One thing that is very symptomatic in the times that are said to be present is digital disruption. The dominant digital disruption is disruption of technology development, especially in the realm of information and communication technology. Existing digital disruption has penetrated industry 4.0. In this industrial era, many things were initiated and developed, for example in terms of optimizing artificial intelligence to support various aspects/ lines of life of today's society. Plural experts liken all people who have been disrupted in this era, and have implemented the maximum utilization of information technology in the joints of their lives, often referred to as society 4.0.

The era of disruption in Society 4.0 has been so widespread. Although this era is still ongoing, citizens of the world are projecting themselves to prepare for the potential direction of the 5.0 era. From this projection, the term of society 5.0 was born that was deprived of this potential. This projection on society 5.0 is likely to become even more symptomatic, widespread, and more massive. People will no longer struggle with implementing technology in various lines of life, but also in more complex, large-scale domains. In this society 5.0, the development of technology integration is not only utilized and able to stand on its own, but also closely integrated with various things in people's lives, including various policies implemented in the community, to help decide the norms in social life.
Perhaps, the range of services extends in the joints of community life 4.0 related to the use of artificial intelligence, one of which is support for the automatization of various vehicles (autonomous vehicles), smart homes (smart-home), to smart cities (smart-city). In the era of society 5.0, these things were further enhanced by integrating it more massively, including in this case the values and norms of society were embedded in such a way. In addition to this, Society 5.0 places more emphasis on a positive social impact.

Referring to Shinzo Abe, society 5.0 includes not only the life of science and technology, but also social-humanities, including literary arts, especially poetry. It is said that the more advanced a civilization, the era is said to be more modern, or an era is said to be more sophisticated, the higher the level of stress, depression, and even mental illness experienced by the community (Lubis, 2014). The higher stress level is influenced by the higher pressure felt by someone. The stress factor can come from disappointment and selfhatred, pressure from the workplace, school, and even instability of the soul in communicating with others in a social community.

Can be exemplified by the case of Nikita Mirzani, her anger became viral (https://www. youtube.com/watch? $=$ =PJ2zVfQL0oI). In addition, the case of Barbie Kumalasari (https:// www.youtube.com/watch? $\mathrm{v}=\mathrm{aVYZx} 2$ bjogc) who seemed happy with variousscornful citizens who said Pansos (Indonesian: panjat sosial, social climbing, another term for piggybacking on the popularity of someone who is more successful/famous) shameless, excessive, and so on, the root of the problem is self-existence and economic factors. The more blasphemed, Barbie Kumalasari received more invitations to appear on television, advertisements, and jobs from various production houses. This condition is very alarming.

Millennials are treated to shows with less educational value, in addition to the interpretation that there is the fastest way to achieve success, which is to make yourself viral by "unusual" or impolite, indecent, impolite, and not weighty in the media. social. This can 
also be seen in the case of Beby Fey who claimed to have been harassed by a YouTuber (https:// www.youtube.com/watch?v=yfnZ1FH8sDg). This phenomenon that occurs in public spaces becomes a pollutant that floods in various social media (Instagram, YouTube, Facebook, and so on).

By looking at the incident, it takes a science in addition to the sciences relating to psychology, psychiatry, counseling, or even religious science, namely the art of literature. Literary works are a place for brainstorming, ideas and experiences to communicate indirectly (Wagiran and Doyin, 2005: 2; Nurudin, 2007: 4). Literary works can be used as a container or media to divert various forms of emotions, such as anger, hatred, inability to control themselves, anxiety, sensation, disappointment, revenge, and so on.

Forms of literary works that can be used as a channel for channeling emotions can be in the form of prose (short stories, novels, continuously stories, or novelettes), poetry (both diaphanous and prismatic types, contemporary, classic, and Rinupa poetry), and drama (both in the form of manuscripts and staging). Things that need to be considered in choosing the type of literary works to be used as a media of "diversion" or emotional therapy for society 5.0 who do not like things that are wordy or tend to be efficient are poetry. Characteristics of poems that are concise in form compared to prose and drama scripts, the density of their meanings because they can "hide" the poet's intentions, and if they are read or recited it takes no long hours.

This is in line with Pradopo (2002: 7) who argues that poetry is a recording and interpretation of important sweet experiences, composed in the form that is most impressed. In line with that opinion, Waluyo (2001: 25) defines poetry as a form of literary work that contains imaginative expressions of poet's thoughts and feelings and is composed by concentrating all the power of language by concentrating its physical structure and inner structure, as well as asserting that poetry is a literary work with language which is compacted, shortened, and given a rhythm with a coherent sound and selection of words (imaginative). Etymologically, Aminuddin (2002: 134) the term poetry comes from the Greek Pócima (means "making") or Poiesis (means "to make"), in English as poem or poetry. The meaning of "making" or "to make" because through poetry basically someone has created a world of its own, which contains messages or images of certain scenes, both physical and inner.

Several studies related to the use of poetry as a way to provide therapy to one's emotions were carried out by Karyanta (2012), resulting in information that the cathartic effect of writing/reading poetry occurs when feelings of anger, hopelessness, pain, guilt, guilt, disappointment, exposure and expression in a supportive environment. Another study was conducted by Farikha (2015) which emphasized poetry therapy carried out with freedom of expression (expressing emotions, feelings, and ideas), not blocking the feelings of the subconscious, and a counselor instilling moral values, courage, politeness, glory, entertainment, motivation, motivation, and other hidden messages. Research related to the use of poetry to provide therapy is also carried out by Kusumawardhani (2017), outlining the steps of counselors in providing counseling to schizophrenia sufferers and clients who are assisted in reflecting their life stress through poetry, both individually and in groups.

Permana (2019) also examined the use of poetry for therapy, described the "procedurs" of poetry used as therapy, "patients" associated with poems that have been chosen to be therapeutic, the aim is to connect the conditions experienced, used as an introduction to emotions that were previously difficult to express, so that someone who is treated feels "relief". Various therapies through poetry as an effort to reduce, divert, and even eliminate stress, emotions, and a variety of unpleasant feelings in a person eventually led to the term Elirica (2013) and steps called POEMS (Perception, Origin, Expression, Medicinal, and Solution), poetry therapy can help someone to recognize how beautiful and valuable he is, rediscover his life purpose, get courage, and the importance 
of self-contribution and affection for other beings.

Lethbridge (2012: 142) states, "Poetry is often associated not only with specialized language but with a very dense use of such specialized language, poems usually try to express their meaning in much less space than, say, a novel or even a short story." Poetry is indeed used as a means of story or brainstorming, expressed more densely words and contains broad meanings. The language in question is a special language to associate something specifically as well. Thus, it can be said that poetry is one type of literary work that is imaginative, concentric, interpretative, sometimes arranged in an unconventional/ unusual or even anti-value form, is a medium to convey the intent of the poet through the delivery of which is implied, full of meaning, packed using aesthetic language. Combined, can be compacted in the form of stanzas, not infrequently the words used in poetry are figurative or symbolic, their appearance is influenced by events that are occurring in certain communities, and can be juxtaposed with pictures/paintings (both through creative and contemplative processes) (Fatimah, 2019: $15)$.

Providing poetry therapy to society 5.0 should also consider information technology in social networking that is used in association, because it will greatly affect the feedback received. The tendency of millennial generation to write "status" or stories in social media in the form of Facebook, Instagram, YouTube, and the like can be used for writing and reading poetry, as a therapeutic medium with the aim of existence and self-actualization. It is important to remember these two goals, existence and self-actualization, because they can "divert" the emotions that flare up in him. In addition, the written results and even poetry readings can be used as an analysis of the level of emotions (low, medium, or high, even severe/critical) possessed and the types of emotions (happy, sad, disappointed, angry, revenge, etc., even how to "cure".

Providing therapy to someone using media poetry cannot be done with only one treatment. Periodic drilling needs to be done, to find out the real emotions that are being experienced and try to hide them, as well as how to "hide emotions" that are honestly expressed into the writing by imitating the meaning/purpose, not an emotion that pretends to be conveyed into poetry form in a manner spontaneous. Therapy is also carried out personally and in groups, with the aim of making a person being treated not only live in their "own world" but open up social sensitivity with others. This therapy can be done online via social media with poetic story writing and commented on by "virtual friends" on Facebook, YouTube, Instagram, or others.

In addition to having a "healing" effect, it is important to consider the quality of poetry created by someone being treated. Therefore, giving therapy in a certain time, a certain period, can make poetry that is created quality. This departs from the positive opinion that anyone can certainly write poetry, regardless of good or bad, or quality of the poem. With such a positive attitude, poetry that is lacking even considered not good or meaningful can be changed, namely by paraphrasing and free paraphrasing techniques.

The bound paraphrase is to change by adding a number of words to the poem but all words in the poem are still used, while the free paraphrase is to change with the words themselves, the words contained in the poem/ original text can be used again or not used anymore (Herlina, 2016: 32-33). Armed with this paraphrase definition, poetry therapy is used with a modified paraphrase technique. The following is an example of implementation. 
Tabel 1. The following is an example of implementation

\begin{tabular}{|c|c|c|}
\hline Step & Instruction & Results \\
\hline $1 \mathrm{st}$ & $\begin{array}{l}\text { 1. Tuliskan apa saja yang terlintas dalam } \\
\text { pikiran atau perasaan kamu sekarang } \\
\text { 2. Tuliskan bentuknya bebas, bisa } \\
\text { berbentuk frasa, klausa, atau kalimat }\end{array}$ & $\begin{array}{l}\text { 1. Ibu pergi ke pasar } \\
\text { 2. Adik membaca Alquran } \\
\text { 3. Sulit memahami Alquran } \\
\text { 4. Aku suka buah Apel } \\
\text { 5. Ayah memancing di sungai belakang } \\
\quad \text { rumah }\end{array}$ \\
\hline 2nd & $\begin{array}{l}\text { 1. Pilih kata yang penting menurut kamu } \\
\text { 2. Hapus kata yang tidak penting menurut } \\
\text { kamu }\end{array}$ & $\begin{array}{l}\text { 1. Ibu } \\
\text { 2. Pasar } \\
\text { 3. Memahami Alquran } \\
\text { 4. Apel } \\
\text { 5. Ayah memancing }\end{array}$ \\
\hline $3 \mathrm{rd}$ & $\begin{array}{l}\text { 1. Gabungkan kata-kata yang telah kamu } \\
\text { pilih } \\
\text { 2. Tambahkan kata-kata lain yang kamu } \\
\text { suka } \\
\text { 3. Kamu bisa menggabungkan atau } \\
\text { menyusun kata-kata yang kamu pilih } \\
\text { sesuka kamu } \\
\text { 4. Susun dalam bentuk baris }\end{array}$ & $\begin{array}{l}\text { Ibu } \\
\text { Memahami Alquran } \\
\text { Tidak semudah membelinya di pasar } \\
\text { Tapi Ketika khusyuk membacanya } \\
\text { mirip Ayah mancing di sungai } \\
\text { belakang rumah } \\
\text { Akan nikmat seperti makan apel }\end{array}$ \\
\hline and so on & $\begin{array}{l}\text { 1. Kamu bisa ganti, hapus, mengurangi, } \\
\text { memindahkan, atau menambah kata- } \\
\text { kata dan konjungsi/kata hubung yang } \\
\text { menurut kamu perlu } \\
\text { 2. Kamu boleh menyusun kata-kata } \\
\text { tersebut dalam susunan yang menurut } \\
\text { kamu bagus }\end{array}$ & $\begin{array}{l}\text { Nikmat Cecap Alquran } \\
\text { Ibu } \\
\text { Memahami Alquran } \\
\text { Tidak semudah membelinya di pasar } \\
\text { Tapi ketika khusyuk membacanya } \\
\text { mirip Ayah mancing di sungai } \\
\text { belakang rumah } \\
\text { Akan nikmat seperti makan apel }\end{array}$ \\
\hline
\end{tabular}

Based on the above process, a poem can be produced in several forms, according to the words used. The form of poetry in question can be seen in the following process.

\section{The 1st Form}

Nikmat Cecap Alquran

$\mathrm{Ibu}$

Memahami Alquran

Tidak semudah membelinya di pasar

Tapi ketika khusyuk membacanya mirip Ayah mancing di sungai belakang rumah Akan nikmat seperti makan apel

The form of the poem can be changed or paraphrased again by the writer at different times and opportunities. Therapy given through media poetry will also determine the level of success in transferring one's emotions.
The therapist should also pay attention to the physical and inner elements of the poem. In line with the opinion of Waluyo (1990: 71-106) that the structure of poetry is divided into two, namely physical structure and inner structure, physical structure consists of (1) diction, (2) imaging, (3) concrete words, (4) figurative language, (5) versification, and (6) typography, and inner structure consists of (1) theme, (2) tone and atmosphere, (3) feeling, and (4) mandate. Meanwhile, Jabrohim (2001: 35-85) that the elements of building poetry include (1) diction, (2) judgment, (3) concrete words, (4) figurative language, (5) versification, (6) typography, and (7) means of rhetoric. Based on a number of opinions related to the structure of poetry, paraphrasing techniques used were also adjusted by considering these elements, so that the following forms of poetry can be seen. 
The 2nd Form

Mencecap Nikmat Alquran

Memahami Alquran

Tidak semudah membelinya di pasar, Ibu

Tapi khusyuk bacanya akan seperti Ayah

mancing dan aku makan apel

\section{The 3rd Form}

\section{Melangitkan Alquran}

Ibu adalah Alquran di dunia yang tiada habis kuselami kasihnya

Cecapan nikmat seperti makan apel

Saat melangitkannya penuh khusyuk
The 4th Form

Segara Langit

Alquran adalah Ibu

Luas kasihnya

Sabar tampak tiada batas

Satu-satunya segara dan langit yang menyatu

Sejuk bagaikan apel tiba-tiba dalam tangan

di kemarau yang sebegini ganas

The potential of poetry as a medium for emotional therapy in society 5.0 can also be seen in the following poetry writing process.

Tabel 2. Poetry writing process

\begin{tabular}{|c|c|c|}
\hline Step & Instruction & Results \\
\hline $1 \mathrm{st}$ & $\begin{array}{l}\text { 1. Tuliskan apa saja yang terlintas dalam } \\
\text { pikiran atau perasaan kamu sekarang } \\
\text { 2. Tuliskan bentuknya bebas, bisa } \\
\text { berbentuk frasa, klausa, atau kalimat }\end{array}$ & $\begin{array}{l}\text { 1. Aku benci kebohongan } \\
\text { 2. Aku benci dibohongi } \\
\text { 3. Kebohongan membuatku hatiku sakit } \\
\text { 4. Aku ingin membalas kebohongan itu } \\
\text { 5. Rasanya sakit sampai sesak bernafas } \\
\text { 6. Bahkan dalam mimpi pun ingin rasanya } \\
\text { aku berteriak memaki-makinya }\end{array}$ \\
\hline 2nd & $\begin{array}{l}\text { 1. Pilih kata yang penting menurut kamu } \\
\text { 2. Hapus kata yang tidak penting menurut } \\
\text { kamu }\end{array}$ & $\begin{array}{l}\text { 1. Benci } \\
\text { 2. dibohongi } \\
\text { 3. hatiku sakit } \\
\text { 4. membalas kebohongan itu } \\
\text { 5. sampai sesak bernafas } \\
\text { 6. Dalam mimpi aku berteriak memaki- } \\
\text { makinya }\end{array}$ \\
\hline $3 \mathrm{rd}$ & $\begin{array}{l}\text { 1. Gabungkan kata-kata yang telah kamu } \\
\text { pilih } \\
\text { 2. Tambahkan kata-kata lain yang kamu } \\
\text { suka } \\
\text { 3. Kamu bisa menggabungkan atau } \\
\text { menyusun kata-kata yang kamu pilih } \\
\text { sesuka kamu } \\
\text { 4. Susun dalam bentuk baris }\end{array}$ & $\begin{array}{l}\text { Dalam mimpi aku berteriak memaki- } \\
\text { Makinya } \\
\text { hatiku sakit } \\
\text { Benci } \\
\text { Sampai sesak bernafas } \\
\text { Dibohongi } \\
\text { tanpa mampu membalas kebohongan } \\
\text { Itu }\end{array}$ \\
\hline $\begin{array}{l}4 \text { th } \\
\text { and so on }\end{array}$ & $\begin{array}{l}\text { 1. Kamu bisa ganti, hapus, mengurangi, } \\
\text { memindahkan, atau menambah kata- } \\
\text { kata dan konjungsi/kata hubung yang } \\
\text { menurut kamu perlu } \\
\text { 2. Kamu boleh menyusun kata-kata } \\
\text { tersebut dalam susunan yang menurut } \\
\text { kamu bagus }\end{array}$ & $\begin{array}{l}\text { Tanpa Mampu Membalas } \\
\text { Dalam mimpi aku berteriak memaki- } \\
\text { Makinya } \\
\text { hatiku sakit } \\
\text { Benci } \\
\text { sampai sesak bernafas } \\
\text { dibohongi } \\
\text { tanpa mampu membalas kebohongan } \\
\text { Itu }\end{array}$ \\
\hline
\end{tabular}

diksi Vol. : 29 No. 1 Maret 2021 
It should be noted that the 4th poem in the table entitled Without Being Able to Reach the above can be continued through the exact same process as the poem entitled Nikmat Cecap Alquran, Mencecap Nikmat Alquran, Melangitkan Alquran, dan Segara Langit. Can be seen through "metamorphosis" which starts from a clause or sentence turns into a draft poem until it develops and ends up as the desired poem. Likewise, with changes in meaning that occur, starting from a set of clauses or sentences that are easy to understand to become a more concise wording can even "hide" the "meaning".

Provision of this treatment will be significantly successful with a measurable and scheduled program design, moreover the poems created are then also read out, both by the original author and others who are also following an emotional therapy program. In other words, someone who is preoccupied with the creative process to produce a work, will not have the time to take care of things that are not his business, more able to control or control even regulate his emotions despite facing a situation that is tiring, annoying, disappointing, and the like. That way, viral cases that horrendous people in the real world who are brought to cyberspace and have a legal impact to the real world (again) will not occur. Society 5.0 in the future is expected to be a society with qualified, insightful, noble character and underlying their lives with faith and piety along with sophistication in the fields of science and technology in all aspects/fields of life.

\section{Discussion}

Poetry is one of the unique literary works. The uniqueness in question lies in its solid form, but its meaning can be many and broad. Poetry was chosen as a therapeutic medium in Society 5.0 because of the tendency for someone to find it difficult to convey everything that is being felt, thought, or experienced with many descriptions, both in writing and orally. Writing literature cannot be done instantly, poetry is no exception. It could be that the process of one poem from the beginning of writing to publication takes decades. The poem can experience an addition, alteration, subtraction, or deletion, both the physical structure (diction, typography, etc.) and the inner structure (especially the message or message).

The findings in this study are 1) therapy is done in two ways, namely writing and reading poems from his writings, 2) writing poetry using paraphrasing techniques, both bound and free, 3) therapy using poetry media is done not only spontaneously but with drilling and periodic systems, 4) poetry is not a medium that can be used to erase or eliminate bad traits, but diverts and controls emotions through a series of processes as therapy, and 5) the results of writing and reading poetry as a therapeutic process can be uploaded to social media as actualization self and channeling the desire to build and maintain the existence of self. some of the findings were not obtained from previous studies with similar topics (Karyanta, 2012; Farikha, 2015; Kusumawardhani, 2017, Permana, 2019).

The form or type of poetry written through the therapeutic process is not only fixated on one form/type. This is consistent with the road map of research on poetry conducted from 2013 to 2019. The research roadmap can be seen in the following figure. 


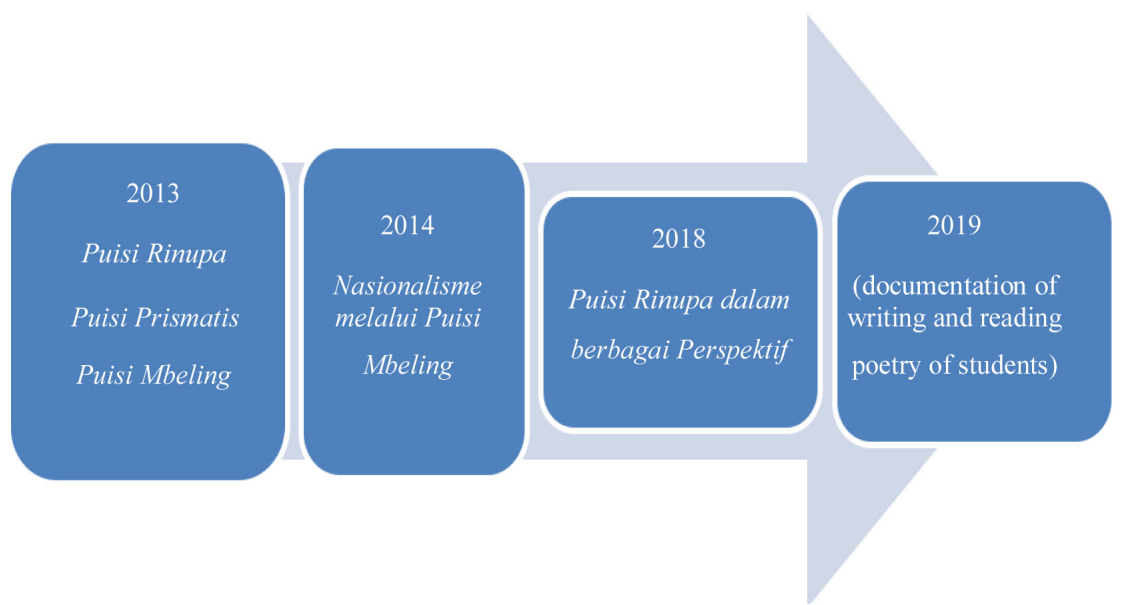

Figure 2. The Research Roadmap of The Authors

In addition, the use of poetry as a medium of emotional therapy in Society 5.0 stimulates the emergence of collaborative studies. Borrowing the terms of the field of linguistics, namely the existence of macrolinguistics (the study of language is related to things outside of language) and microlinguistics (the study of language is only about the structure without involving other fields), so can the emergence of micro-literature (literary works are examined autonomously only the building elements) and macro-literature; literary works are examined by linking them with other fields (anthropology, sociology, psychology, including for emotional therapy). These findings can be seen in the following figure.

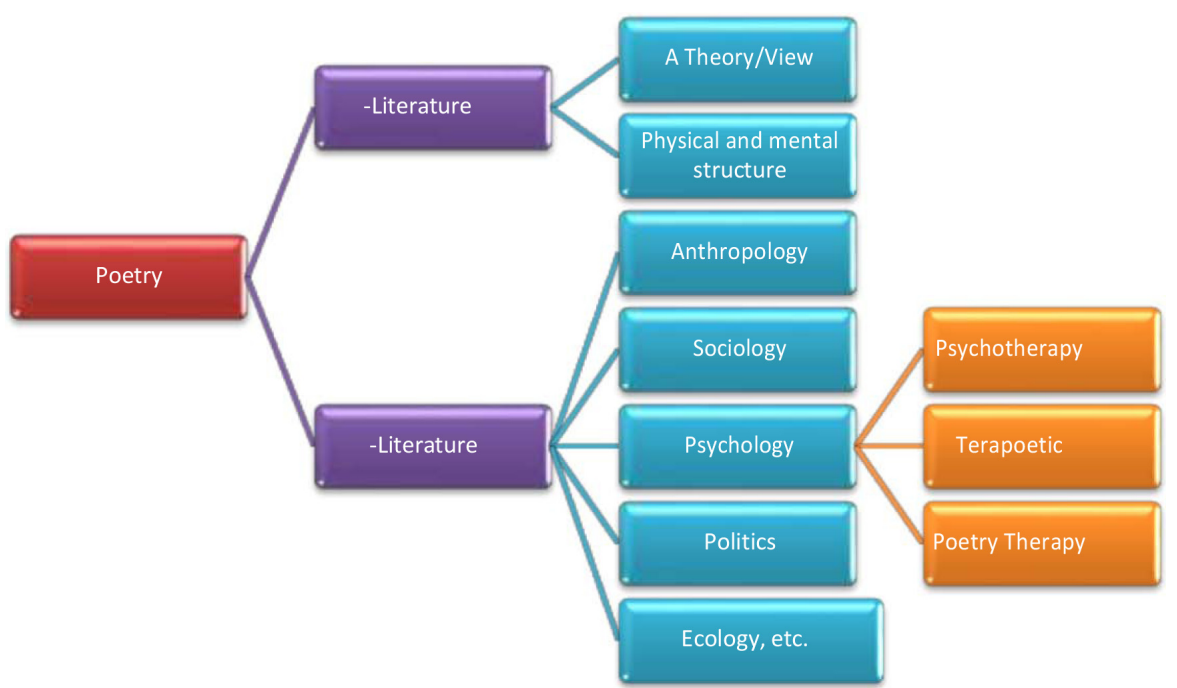

Figure 3. Poetry as A Medium of Emotional Therapy

\section{CONCLUSION}

Based on this literature research it can be concluded that poetry has the potential as a medium of emotional therapy for Society 5.0. Therapy is given through the process of writing and reading that is given by drilling and in a vulnerable periodic time. In addition, poetry formulas were found which are used as a therapeutic medium by using paraphrase techniques, both bound and free paraphrasing. The use of poetry as a therapeutic medium is a literary study that is not only in the micro scope, but also macro. The research conducted can be said to be still an exploratory stage and can be open for further research, especially experimental research and development in 
the fields of models, methods, media, and so on, including receptions by Society 5.0 as stakeholders of the users of the products of its development research. This proves that literature, especially poetry, is open to other types of science, all fields of life, even evolutionarily following changes and developments in human civilization.

\section{REFERENCES}

Aminudin. (2002). Pengantar Apresiasi Karya Sastra. Bandung: Sinar Baru Algensindo.

Dewi, E. K. (2018). Nilai-Nilai Pendidikan Karakter dalam Novel Laut Bercerita karya Leila S. Chudori dan Kemungkinannya sebagai Bahan Ajar Sastra di SMA/SMK. Skripsi. http:// lib.unnes.ac.id/32449/1/2101411132. pdf

Farikha(2015). Terapi Puisi.http://diaryfarikha. blogspot.com/2015/06/terapi-puisi. $\underline{\mathrm{html}}$

Fatimah, S. (2008). Relasi Gambar Ilustrasi dengan Teks Puisi Air Kata Kata Karya Sindhunata. Skripsi. Universitas Negeri Semarang.

Fatimah, S. (2013). Bentuk dan Jenis Puisi Prismatis dalam Kumpulan Puisi Air Kata Kata Karya Sindhunata. Jurnal MALIH PEDDAS, 3 (2).

Fatimah, S. (2018). Islamic Javanese Ideas in The Poetry Collection of Air Kata Kata by Sindhunata. Jurnal Ibda' Purwokerto.

Fatimah, S. (2018). Multicultural Values on Poetry Collection of Air Kata Kata by Sindhunata in Social Semiotic Perspective. Prosiding Seminar yang diselenggarakan Universitas Sarjana Tamansiswa Yogyakarta.

Fatimah, S. (2018). Sindhunata dengan Air Kata Kata: Pelopor Puisi Rinupa. Prosiding Seminar Nasional yang diselenggarakan oleh Universitas Sanata Darma.

Fatimah, S. dan Ngatmini. (2014). Puisi Mbeling Sebagai Aset Pemertahanan Nasionalisme Generasi Bangsa dalam
Kumpulan Puisi Air Kata Kata Karya Sindhunata. Seminar Internasional diselenggarakan oleh Balai Bahasa Lombok

Fatimah, S. 2019. Kumpulan Puisi Air Kata Kata Karya Sindhunata dalam Perspektif Semiotika Sosial. Disertasi. Surakarta: UNS.

Hardila, L. (2018). Peran Sastra dalam Membentuk Karakter Siswa. https:// www.kompasiana.com/lanyhardila/ 5bfaabb86ddcae139b412056/peransastra-dalam-membentuk-karaktersiswa?page $=$ all

Jabrohim (ed). 2001. Metodologi Penelitian Sastra. Yogyakarta: Hanindita Graha Widia.

Karyanta, N. A. (2012). Terapi Puisi: DasarDasar Penggunaan Puisi sebagai Modalitas dalam Psikoterapi. Wacana: Jurnal Psikologi, Vol. 4, No. 1.https:// jurnalwacana.psikologi.fk.uns.ac.id/ index.php/wacana/article/view/3 4

Kemala, I. N. (2017).Pengaruh Terapi Menulis Puisi Terhadap Harga Diri Siswa (Studi Kuasi Eksperimen Terhadap Siswa dengan Harga Diri Rendah di SMK

Farmasi Mandala Tiara Bangsa).http://journal. unj.ac.id/unj/index.php/insight/article/ download/1639/1289/

Kusumawardhani, D (2017). Pendekatan Konseling Terapi Puisi. https://www. academia.edu/30457417/Pendekatan Konseling Terapi puisi atau https:// caridokumen.com/download/ pendekatan-konseling-terapi-puisi5a469686b7d7bc7b7a11f3b0 pdf

Lethbridge, S. \& Jarmila, M. (2012). Basics of English Studies: an Introductory Course for Students of Literary Studies in English. Basics of English Studies, Version 12/03, Poetry. Developed at the English Departments of the Universities of Tubingen, Stuttgart and Freiburg.

Lubis, N. (2014). Stres di era Modern. https://www.kompasiana.com/nikmah. 
$\underline{\text { lubis/54f91f1aa33311ac048b46a8/ }}$ stres -di-era-modern

Ngatmini dan Fatimah, S. (2013). Keefektifan Model Think Pairs Share dalam Pembelajaran Apresiasi Puisi Rinupa Mahasiswa Pendidikan Bahasa dan Sastra Indonesia IKIP PGRISemarang. Semarang: Digilib UPGRIS.

Ngatmini dan Fatimah, S. (2013). Pengembangan Model Pembelajaran Menulis Puisi Mbeling dengan Media ICT Berbasis Practical Rehearsal Pairs pada Mata Kuliah Apresiasi Puisi Mahasiswa PBSI IKIP PGRI Semarang. Semarang: Digilib UPGRIS.

Nurudin. (2007). Dasar-dasar Penulisan. Solo: UMM Press.

Pemberitaan Barbie Kumalasari melabrak Wulan Ye https://www.youtube. com/watch? v=aVYZx2bjog c dan https://www.youtube.com/ watch? $\mathrm{v}=\mathrm{d} 9 \mathrm{jz} 1 \mathrm{viTU} 5 \mathrm{k}$

Pemberitaan Beby Fey. P3H - Klarifikasi Beby Fey Yang Diduga Dapatkan Pelecehan Seksual Oleh Youtuber (10/9/19) Part 1. https://www.youtube.com/ watch?v=yfnZ1FH8sDg
Pemberitaan Nikita Mirzani bertengkar dengan Elza Syarief https://www.youtube. com/watch? $\mathrm{v}=\mathrm{PJ} 2 \mathrm{zVfQL0oI}$

Permana, R. W. (2019). Terapi Puisi, Cara Penyembuhan Jiwa dengan Kata-Kata Bermakna. Merdeka.com (Kamis, 3 Januari 2019 11:36). https://www. merdeka.com/sehat/terapi-puisi-carapenyembuhan-jiwa-dengan-kata-katabermakna.html

Pradopo, R. D. (2002). Pengkajian Puisi. Yogyakarta: Gadjah Mada University Press.

Puskomedia (2019). Masyarakat 5.0 Masa Depan Baru Indonesia. https://www. puskomedia.id/masyarakat-5-0

Terapi Elirica: Terapi Puisi (2013). http:// terapielirica.blogspot.com/2013/11/ terapi-puisi.html

Wagiran dan Doyin (2005). Curah Gagasan, Pengantar Penulisan Karya Ilmiah. Semarang: Rumah Indonesia.

Waluyo, H. J. (2001). Teori dan Apresiasi Puisi. Jakarta: Erlangga. 